7. Кузьмич О. Я. Договори на користь третіх осіб у цивільному праві України: монографія. ІваноФранківськ: вид-во Прикарпат. нац. ун-ту ім. В. Стефаника, 2014. 333 с.

8. Боднар Т. В. Суб'єкти виконання договірного зобов'язання. Підприємництво, господарство i право. 2004. № 6. С. 28-33.

9. Токарєва В. І. Цивільне право України. Практикум: навч. посібник. Київ: Центр учбової літератури, 2007. $408 \mathrm{c}$.

10. Договірне право України. Загальна частина: навч. посіб. / Т. В. Боднар, О. В. Дзера, Н. С. Кузнєцова та ін.; за ред. О. В. Дзери. Київ: Юрінком Інтер, 2008. 896 с.

11. Утехін І. Б. Виконання договорів 3 передачі майна у власність: дис. ... канд. юрид. наук: 12.00.03. Київ: Київський національний університет імені Тараса Шевченка, 2009. 218 с.

12. Гражданское право: учебник для вузов. Академический курс / Отв. ред. М. К. Сулейменов, Ю. Г. Басин. Алма-Аты: КазГЮА, 2000. Т. 1. 702 с.

13. Клепікова О. В. Правове регулювання перевезень вантажів морським транспортом: дис. ... канд. юрид. наук: 12.00.04. Київ: Київський національний університет імені Тараса Шевченка, 2003. 228 с.

14. Безлюдько I. О. Договір перевезення вантажу повітряним транспортом за цивільним правом України: дис. ... канд. юрид. наук: 12.00.03. Київ: Національна академія внутрішніх справ України, 2005. $197 \mathrm{c}$.

15. Луць В. В. Строки і терміни у цивільному праві: монографія. Київ: Юрінком Інтер, 2013. 320 с.

\title{
Lukasevych-Krutnyk I. Elements of carriage of transport services liability
}

The article is devoted to the study of issues related to the definition of elements of the implementation of obligations for the provision of transport services. The following elements of fulfillment of obligations on the provision of transport services are specified: actors of execution; subject of execution; mode of execution; term of execution; place of execution. The attention is focused on cases of suspension of fulfillment of obligations on the provision of transport services under long-term contracts.

Keywords: elements of performance of contractual obligations, subject of performance, subject of execution, manner of execution, term of execution, place of execution, long-term contracts, suspension of execution.

\section{НЕУСТОЙКА ЯК СПОСІБ ЗАБЕЗПЕЧЕННЯ ВИКОНАННЯ ЗОБОВ'ЯЗАНЬ ЗА ДОГОВОРОМ СТРАХУВАННЯ}

\author{
https://doi.org/10.32849/2409-9201.2019.19.28
}

\section{Міловська Н. В.,}

кандидат юридичних наук, доцент, старший науковий співробітник відділу проблем приватного права НДІ приватного права і підприємнищтва імені академіка Ф. Г. Бурчака НАПрН України

У науковій статті визначено характерні ознаки неустойки як особливого виду забезпечення виконання страхових зобов'язань. 3'ясовано особливості застосування законної $і$ договірної неустойки. Встановлено, що неустойка в договірних зобов'язаннях зі страхування, з одного боку, спрямована на стимулювання належного виконання відповідного зобов'язання боржником иляхом встановлення додаткових гарантій задоволення інтересів контрагента за договором страхування, а з іншого спрямована на встановлення додаткового обов'язку - сплатити чи передати неустойку.

Ключові слова: договір страхування, неустойка, забезпечення виконання зобов'язань, належне виконання, способи забезпечення.

Належне виконання зобов'язань передбачає, що сторони, які беруть участь у зобов'язальних правовідносинах, виконують покладені на них обов'язки відповідно до закону, договору, а за відсутності таких зазначень - відповідно до звичаїв ділового обороту або ж до вимог, які, зазвичай, висуваються до сторін виконання. Кожна зі сторін у рамках цивільно-правових відносин зацікавлена в належному виконанні зобов'язань своїм контрагентом. Так, на думку Є. О. Суханова, основою виникнення всіх зобов'язань $є$ переконання сторін щодо перспективи виконання контрагентом тих дій, які необхідні для задоволення потреб зацікавленої сторони [1, с. 107].

Сторони договору страхування, за яким здійснюється надання страхової послуги страховиком страхувальникові, дотримуючись принципу добросовісності, мають враховувати інтереси один одного, піклуватися не тільки про свою персональну вигоду, а й про те, щоб інша сторона отримала те, на що вона розраховувала, укладаючи договір [2, с. 12]. Належне виконання страхових зобов'язань стимулює зміцнення майнового становища учасників цих відносин, формування у них впевненості в реалізації визначених завдань. 
Для забезпечення максимально належного виконання сторонами своїх зобов'язань законодавцем передбачені спеціальні «інструменти» впливу на кожну зі сторін. I тут доцільно погодитись із тезою, що саме меті належного виконання зобов'язання підпорядковані різні способи забезпечення [3, с. 58].

Проблематика зобов'язань, їх виконання та способи їх забезпечення і зараз є предметом жвавих дискусій серед вчених-цивілістів. Так, на думку І.Й. Пучковської, відсутність у законі поняття забезпечення виконання зобов'язання, віднесення до їх складу мір відповідальності, поповнення забезпечень притриманням та відкритий перелік породжують у науці цивільного права різні точки зору щодо природи даних мір [4, с. 26].

Забезпечувальне зобов'язання - це правовідношення, що виникло на підставі правової норми (договору чи закону) внаслідок порушення основного забезпечувального зобов'язання його стороною, виконання якого (залежно від виду забезпечення) спрямоване на стимулювання боржника до належного виконання обов'язків та/або на захист інтересів кредитора [5, с. 187].

Законодавець у Цивільному кодексі України (далі - ЦК України) окрему гл. 49 присвятив особливостям правового регулювання забезпечення виконання зобов'язань та відповідним їх видам. На доктринальному рівні види забезпечення виконання зобов'язання класифікуються за різними критеріями (залежно від суб'єктного складу, від джерела закріплення, за обсягом відповідальності, за можливістю розміщення в основному зобов'язанні тощо).

Відповідно до положень ст. 546 ЦК України виконання зобов'язань може бути забезпечено неустойкою, заставою, притриманням, порукою, гарантією, завдатком та іншими способами, передбаченими законом або договором. Тобто в ЦК України відображено підхід, за яким виконання зобов'язання може забезпечуватися не тільки тими способами, які прямо передбачені у ЦК України, а й тими, що встановлені у спеціальних нормативно-правових актах (наприклад, у Законі України «Про страхування») або ж визначені сторонами в самому договорі. На це звертає увагу і Н. С. Кузнєцова, підкреслюючи, що сучасні тенденції розвитку законодавства щодо способів забезпечення виконання зобов'язання передбачають значне розширення кола таких правових засобів, якими може скористатися кредитор з метою встановити додаткові гарантії, спрямовані на забезпечення виконання зобов'язання [6, с. 59].

Забезпечувальні засоби перебувають в пасивній формі, і в такій формі вони виконують роль охоронного характеру, оскільки їх зміст спрямований лише на спонукання до: а) обов'язкового виконання договірних зобов'язань; б) дотримання строків виконання договорів; в) вчасної оплати об'єктів договірних зобов'язань; г) якості товарів, робіт чи послуг. Активної форми такі засоби набувають лише на основі сукупності двох фактів: а) невиконання чи неналежного виконання договірних зобов'язань; б) волевиявлення кредитора [7, с. 77].

На нашу думку, основне завдання способів забезпечення виконання зобов'язань в цілому та страхових зокрема полягає, по-перше, в стимулюванні боржника до належного виконання зобов'язання через настання в іншому випадку негативних наслідків, по-друге, гарантуванні належного виконання взятих перед кредитором зобов'язань, що виступає додатковим стимулом до вступу останнього в зобов'язання i, нарешті, стимулювання грошового обороту.

Одним із способів забезпечення належного виконання страховиком взятих на себе зобов'язань $\epsilon$ неустойка. У ст. 549 ЦК України неустойка (штраф, пеня) визначається як грошова сума або інше майно, яке боржник повинен передати кредиторові у разі порушення боржником зобов'язання. У більшості випадків вона співвідноситься 3 розміром заподіяних кредитору невиконанням зобов'язання збитків. Крім того, жодних додаткових майнових гарантій кредитор не набуває: боржник або відшкодовує збитки (залікова неустойка), або сплачує лише їх частину (виключна неустойка). У штрафній же неустойці виявляється ії забезпечувальний характер - кредитор отримує грошову суму незалежно від наявності чи відсутності збитків.

Крім ЦК України, норми про неустойку знайшли своє відображення також і в Господарському кодексі України, в ст. 230 якого під штрафними санкціями розуміються господарські санкції у вигляді грошової суми (неустойка, штраф, пеня), яку учасник господарських відносин зобов'язаний сплатити у разі порушення ним правил здійснення господарської діяльності, невиконання або неналежного виконання господарського зобов'язання.

Згідно зі ст. 992 ЦК України у разі несплати страховиком страхувальникові або іншій особі страхової виплати страховик зобов'язаний сплатити неустойку в розмірі, встановленому договором або законом. У свою чергу, відповідно до п. 36.5 ст. 36 Закону України «Про обов'язкове страхування цивільно-правової відповідальності власників наземних транспортних засобів» [8] за кожен день прострочення виплати страхового відшкодування (регламентної виплати) з вини страховика (МТСБУ) особі, яка має право на отримання такого відшкодування, сплачується пеня з розрахунку подвійної облікової ставки Національного банку України, яка діє протягом періоду, за який нараховується пеня. Однак, як зазначає Т. 3. Джамалов, у разі якщо судом буде встановлено, що вигодонабувач зловживав 
своїм правом на отримання страхової виплати, йому може бути відмовлено в частині стягнення суми неустойки [9, с. 35].

Аналізуючи неустойку як спосіб забезпечення виконання страхових зобов'язань, слід підтримати позиції тих вчених, які вказують на подвійну природу неустойки, що виявляє себе як гарантія виконання зобов’язання і міра відповідальності (як штрафна санкція) [10, с. 49]. Так, І. Й. Пучковська під кутом зору визнання видів забезпечення виконання зобов'язання способами захисту прав кредитора у договорі розглядає питання щодо подвійної природи неустойки [4, с. 29]. Цю саму думку поділяє і О. О. Отраднова, підкреслюючи, що правова природа неустойки залежить від «етапу існування неустойки в зобов'язальних правовідносинах» [11, с. 9]. Саме небажання нести додаткові майнові витрати, несприятливість, невигідність негативних наслідків і спонукає особу до належної поведінки. У зв'язку з цим неустойка виконує стимулюючу (превентивну) функцію. У разі порушення основного зобов'язання боржником кредитор має право на стягнення неустойки, але якщо боржник не виконує свій обов'язок сплатити неустойку, то кредитор лише має право вимагати від нього, крім виконання основного зобов'язання, ще й сплати неустойки. Тобто, крім збитків, заподіяних невиконанням зобов'язання, боржник має сплатити ще й неустойку, якщо вона була встановлена сторонами в договорі або передбачена законом за порушення зобов'язання.

Як зазначає Д. В. Кушерець, неустойка, якою є штраф, що обраховується у відсотках від суми невиконаних або неналежно виконаних зобов'язань, чи пеня, що нараховується у відсотках на суму несвоєчасно виконаних грошових зобов'язань за кожний день прострочення зобов'язань (ст. 549 ЦК України), відіграє роль майнової відповідальності кредитора за неналежне виконання своїх договірних зобов'язань чи невжиття заходів щодо зменшення своїх же матеріальних збитків [7, с. 77].

Поділяючи в цілому думку щодо подвійної природи неустойки, О. І. Гелевей вважає, що за певних обставин неустойка продовжує виконувати свою забезпечувальну функцію і в разі порушення строків виконання зобов'язання, оскільки остаточний розмір відповідальності боржника перебуває в пропорційній залежності від тривалості невиконання зобов'язання [12, с. 11]. Такий підхід, на нашу думку, надає змогу більш детально з'ясувати правову природу неустойки, яка, з одного боку, спрямована на стимулювання належного виконання зобов'язання боржником шляхом встановлення додаткових гарантій задоволення інтересів контрагента за договором страхування, а 3 іншого спрямована на встановлення додаткового обов'язку - сплатити чи передати неустойку.

Слід звернути увагу на законодавче розширення кола предметів, що можуть передаватися боржником як неустойка у випадку невиконання або неналежного виконання договорів, що видається, зважаючи на розширення договірної свободи, цілком виправданим підходом. Так, законодавець у загальній нормі ст. 551 ЦК України визначає, що предметом неустойки може бути грошова сума, а також рухоме і нерухоме майно.

Однак в юридичній літературі існують й інші міркування, а саме пропозиції щодо необхідності звуження предмета неустойки шляхом визначення іії виключно у грошовій формі [13, с. 9]. Так, зокрема, у ст. 330 ЦК РФ зазначено, що неустойкою визнається визначена законом чи договором грошова сума, яка сплачується у випадку невиконання чи неналежного виконання зобов'язання, а саме, у випадку прострочення виконання [14]. Схожий підхід відображено і в ст. 296 ЦК Республіки Казахстан [15]. Виключно з грошовою сумою пов'язує зміст неустойки ст. 417 ЦК Республіки Грузія [16]. Неустойка в грошовій сумі встановлена і в ЦК Республіки Узбекистан [17]. Такий підхід видається необгрунтованим та таким, що важко сприйматиметься в сучасних умовах розвитку договірних відносин, зважаючи хоча б на те, що широке розуміння неустойки сформувалось у нас доволі давно.

За підставами формування розрізняють законну і договірну неустойку. Застосування положень імперативних норм щодо включення до змісту договорів страхування умов, які стосуються забезпечення виконання зобов'язання, свідчить, перш за все, про турботу законодавця щодо економічно слабшої сторони в договірних відносинах - страхувальника, а з іншої сторони - про певні гарантії, які надаються страховику, який виконує зобов'язання щодо надання страхової послуги.

На принципово інших засадах формується договірна неустойка, оскільки самим сторонам, а не законодавцю, надано право визначати для себе умови застосування договірної неустойки та ії безпосередній розмір за неналежне виконання або невиконання договорів страхування. Як виняток, у разі виникнення переддоговірного спору за згодою сторін це питання може бути передано на вирішення суду.

У свій час Д. І. Мейєр вважав, що договірна неустойка найчастіше встановлюється в тих випадках, коли порушення прав однієї зі сторін невиконанням договору не тягне за собою значної шкоди для кредитора. Кредитор втрачає юридичний інтерес до виконання. На його думку, встановлення договірної неустойки також зумовлено тією обставиною, що не завжди $є$ можливість однозначно визначити шкоду [18, с. 185].

Варто зазначити, що за рішенням суду розмір неустойки може бути зменшений за наявності однієї з таких умов: а) якщо розмір неустойки значно перевищує розмір завданих збитків; б) за наявності інших обставин, які мають істотне значення (ч. 3 ст. 551 ЦК України). Істотне значення для зменшення розміру неустойки можуть мати обставини, які стосуються ступеня виконання зобов'язання, 
причин невиконання або неналежного виконання, незначного прострочення у виконанні зобов’язання, негайного добровільного усунення винною стороною порушення та його наслідків тощо [19, с. 109].

Висновки. Отже, для неустойки як особливого виду забезпечення виконання страхових зобов' язань характерні такі ознаки: а) вона спрямована на попередження невиконання чи неналежного виконання умов договорів страхування; б) iї застосуванню передує невиконання чи неналежне виконання боржником передбачених договором страхування зобов'язань, що є підставою для покладення на останнього негативних наслідків майнового характеру; в) стягненням неустойки компенсуються ті втрати, які зазнав кредитор у зв'язку з невиконанням умов договору страхування; г) стягнення неустойки одночасно виконує попереджувальну і виховну функцію, оскільки сигналізує боржнику про негативні наслідки, які настануть у разі невиконання ним страхових зобов'язань; д) неустойка як вид забезпечення виконання страхових зобов'язань впливає на боржника з моменту укладання договору, а iї безпосереднє застосування пов'язано з невиконанням чи неналежним виконанням зобов'язання; е) у неустойки в страхових зобов'язаннях відсутня ознака, характерна для інших видів забезпечення виконання зобов' язання - наявність додаткової гарантії виконання зобов’язання.

\section{СПИСОК ВИКОРИСТАНОЇ ЛІТЕРАТУРИ:}

1. Суханов Е. А. Гражданское право в 3-х томах. М.: Издательство «Юристъ», 2001. 356 с.

2. Kotz H., Flessner A. European Contract Law. Oxford, 1997. Vol. 1: Formation, Validity and Content of Contracts; Contract and Third Parties / transl. by T. Weir. Oxford, 1997. P. 12.

3. Зобов’язальне право: теорія і практика: навч. посібн. для студентів юрид. вузів і фак. ун-тів / О. В. Дзера, Н. С. Кузнєцова, В. В. Луць та інші; за ред. О. В. Дзери. К.: Юрінком Інтер, 1998. С. 58.

4. Пучковська I. Й. Види забезпечення виконання зобов’язання як способи захисту // Юридична Україна. 2011. № 11. С. 26.

5. Боднар Т. В. Договірні зобов'язання в цивільному праві: заг. положення: навч. посіб. К.: Юстиніан, 2007. С. 187.

6. Зобов'язальне право: теорія і практика: навч. посібник для студентів юрид. вузів і фак. ун-тів / За ред. О. В. Дзери. Стереотип. вид. К.: Юрінком Інтер, 2000. С. 59.

7. Кушерець Д. В. Забезпечення виконання договірних зобов'язань як гарантія охорони та захисту майнових прав // Часопис цивілістики. 2014. Випуск 17. С. 76-79.

8. Про обов'язкове страхування цивільно-правової відповідальності власників наземних транспортних засобів: Закон України від 1 липня 2004 р. // Відомості Верховної Ради України. 2005. № 1. Ст. 1.

9. Джамалов Т. 3. Неустойка как один из способов обеспечения надлежащего исполнения обязательств сторонами по договору ОСАГО // Научно-практический электронный журнал Аллея Науки». 2017. № 10.

10. Браніцький О., Шароватова А. Інститут неустойки в господарських правовідносинах: теоретичний $\mathrm{i}$ практичний аспекти // Підприємництво, господарство і право. 2011. № 4. С. 49.

11. Отраднова О. О. Неустойка в цивільному праві: автореф. дис. ... канд. юрид. наук: 12.00 .03 / Київ. нац. ун-т ім. Т. Шевченка. К., 2002. С. 9.

12. Гелевей О. І. Неустойка як вид забезпечення виконання зобов’язання: автореф. ... дис. канд. юрид. наук: 12.00.03. К., 2003. С. 11.

13. Проценко I. О. Види забезпечення належного виконання зобов'язань у цивільному праві України: єдність та диференціація: автореф. ... дис. канд. юрид. наук: 12.00.03. X, 2007. С. 9.

14. Гражданский кодекс Российской Федерации. Електронний ресурс. URL: https://base.garant.ru/ 10164072/ (дата звернення: 28.12.2018).

15. Гражданский кодекс Республики Казахстан. Електронний ресурс. URL: http://online.zakon.kz/ Document/?doc_id=1006061(дата звернення: 28.12.2018).

16. Гражданский кодекс Республики Грузия. URL: https://matsne.gov.ge/ ru/document/download/31702/ 75/ru/pdf (дата звернення: 28.12.2018).

17. Гражданский кодекс Республики Узбекистан. URL: http://fmc.uz/ legisl.php?id=k_grajd (дата звернення: 28.12.2018).

18. Мейер Д. И. Русское гражданское право: в 2-х ч. М.: Статут, 1997. Ч. 2.С. 185.

19. Луць В. В. Контракти в підприємницькій діяльності: навч. посіб. 2-е вид., перероб. і допов. К.: Юрінком Інтер, 2008. С. 109.

Milovska N. Forfeit as a way to provision of execution of obligations under the insurance contract

In the scientific article the characteristic features of a forfeit, as a special type of provision of execution of insurance obligations are defined, the peculiarities of the application of legal and contractual forfeits are clarified. It was established that the forfeit in contractual insurance obligations, on the one hand, is aimed at stimulating the debtor to execution the relevant obligation by establishing additional guarantees for satisfying the interests of the counterparty under the insurance contract, and on the other, it is aimed at establishing an additional obligation to pay or transfer forfeit.

Key words: insurance contract, forfeit, enforcement of obligations, proper execution, methods of providing. 